\title{
STRATEGI PEMECAHAN MASALAH MATEMATIS VERSI GEORGE POLYA DAN PENERAPANNYA DALAM PEMBELAJARAN MATEMATIKA
}

\author{
Wahid Umar \\ Universitas Khairun \\ wahidun0801@gmail.com
}

\begin{abstract}
ABSTRAK
George Polya telah meletakan suatu warisan "pentingnya mengajar dengan pemecahan masalah". Setiap masalah memiliki "sepuluh strategi" yang tepat dengan "empat" langkah pemecahan sesuai dengan aspek-aspek dan sudut pandangnya masing-masing di dalam menyelesaikan suatu masalah matematis. Topik ini telah menjadi komponen utama dalam kurikulum matematika pada semua tingkatan pendidikan. NCTM dalam standards (1989) mempublikasikan "The Curriculum and Evaluations Standards for School Mathematics", yang menekankan bahwa pemecahan masalah harus menjadi fokus dalam kurikulum matematika di sekolah. Ini berarti bahwa pemecahan masalah merupakan salah satu topik yang sangat penting dalam pembelajaran matematika. Tujuan mengajarkan matematika dengan pemecahan masalah adalah: (1) membantu guru memperbaiki keterampilan pemecahan masalah diri sendiri; (2) diberikan kepada guru untuk membantu siswa mengembangkan keterampilan pemecahan masalah mereka; (3) untuk menyelidiki strategi umum pemecahan masalah; dan (4) bagaimana membuat kata "masalah" dan "pemecahan masalah" menantang dan menarik untuk siswa. Pentingnya para siswa mengalami proses pembelajaran matematika dengan pemecahan masalah matematis. Siswa perlu dipersiapkan dan didorong untuk berpikir bahwa sesuatu itu multi-dimensi sehingga mereka dapat melihat banyak kemungkinan penyelesaian untuk suatu masalah. Dengan demikian, pemecahan masalah matematis dalam pembelajaran matematika merupakan bagian integral dari semua aktivitas matematis. Fokus kajian makalah ini adalah bagaimana strategi pemecahan masalah matematis versi George Polya dan penerapannya dalam pembelajaran matematika.
\end{abstract}

Kata Kunci : pembelajaran, pemecahan masalah, Polya dan langkah-langkah pemecahannya

\section{PENDAHULUAN}

Tujuan pembelajaran matematika dalam kurikulum di antaranya adalah: siswa dapat memecahkan masalah serta memiliki sikap menghargai kegunaan matematika dalam kehidupan, sikap rasa ingin tahu, perhatian, dan minat dalam mempelajari matematika, serta sikap ulet dan percaya diri dalam memecahkan masalah (Depdiknas, 2006). Dalam NCTM (2001) menamakan tujuan dalam aspek afektif di dalam kurikulum matematika dengan istilah mathematical disposition. Demikian pula Katz (2009), mengemukakan bahwa disposisi matematis memuat rasa percaya diri, tekun, berminat, dan berpikir fleksibel dalam mengeksplorasi berbagai alternatif strategi penyelesaian masalah. Sebagai bagian dari tujuan pembelajaran matematika, maka pemecahan masalah (problem solving) 
merupakan suatu keniscayaan dan sangat penting dikembangkan pada siswa yang belajar matematika.

Pemecahan masalah merupakan suatu topik yang banyak menarik perhatian para pendidik dan salah satu topik penting dalam pembelajaran matematika di banyak negara. Sebagai contoh, topik ini di sarankan oleh National Council of Teachers of Mathematics (NCTM). Sebagai titik fokus kurikulum matematika sekolah di Amerika Serikat (NCTM, 2001) dan dikembangkan di Jepang sebagai suatu pendekatan untuk memahami konsepkonsep matematika. Topik ini telah menjadi komponen utama dalam kurikulum matematika pada semua tingkatan pendidikan. Mengingat pemecahan masalah matematika merupakan salah satu kegiatan matematika yang dianggap penting baik oleh para guru maupun siswa. Dengan demikian, pemecahan masalah dalam pembelajaran matematika merupakan bagian integral dari semua aktivitas matematis.

Dari tahun ke tahun, pemecahan masalah muncul sebagai salah satu perhatian utama disemua tingkatan matematika sekolah. The national council of supervisors of mathematics (NCSM) menyatakan "belajar menyelesaikan masalah adalah alasan utama untuk memperlajari matematika" (NCSM, 1997). Premis tersebut tidak berubah banyak dalam tahun-tahun belakangan ini, dan malah menjadi suatu perihal yang makin kuat. NCSM menyatakan secara tegas dalam principles and standard for mathematics (NCTM, 2001)"problem solving bukanlah sekedar tujuan dari belajar matematika tetapi juga merupakan alat utama untuk melakukannya". Di sisi lain, NCTM (2003) menyatakan bahwa pemecahan masalah bukanlah suatu topik yang terpisah, melainkan suatu proses yang harus dapat menyerap seluruh program, dan menyediakan suatu konteks dimana konsep dan keterampilan dapat dipelajari. Para guru harus mengetahui faktor-faktor yang mempengaruhi pemecahan masalah ini sehingga mereka dapat mengantisipasi kesulitankesulitan yang mungkin dihadapi oleh para siswa dan memberikan jalan-jalan yang tepat. Para siswa perlu dipersiapkan dan didorong untuk berpikir bahwa sesuatu itu multidimensi sehingga mereka dapat melihat banyak kemungkinan penyelesaian untuk suatu masalah.

Tuntutan dalam dokumen-dokumen standards NCTM (2003) juga telah merekomendasikan pentingnya para siswa mengalami proses pembelajaran matematika dengan pemecahan masalah. Tuntutan ini dimaksudkan agar siswa mampu menghadapi perubahan keadaan pada dunia matematika yang selalu berkembang. Namun dalam keseharian baik siswa, mahasiswa maupun guru kemampuan pemecahan masalah umumnya masih terlihat kurang, dan tampaknya guru masih terjebak pada filosofi dan 
strategi lamanya. Ini menunjukkan bahwa kegiatan pemecahan masalah dalam proses pembelajaran matematika di sekolah belum dijadikan sebagai kegiatan utama, bahkan menjadi penghambat dalam meningkatkan kemampuan siswa di sekolah. Padahal, di negara-negara maju seperti Amerika Serikat dan Jepang merupakan inti dari kegiatan pembelajaran matematika di sekolah.

Untuk menjawab tuntutan perubahan dunia matematika yang demikian tinggi, maka guru perlu dikembangkan materi serta proses pembelajaran melalui pemecahan masalah berupa permasalahan dalam matematika. Hal ini jelas dalam proses pembelajaran matematika, guru harus mengetahui strategi pemecahan masalah sebelum memberikan kepada siswa. Oleh karena itu, mau tidak mau permasalahan matematika yang dihadapi siswa tersebut harus diselesaikan, namun metode atau cara penyelesaiannya tidak diketahui.

Karena metode penyelesaian masalah yang dihadapi tidak diketahui, hal ini mengakibatkan berbagai kesulitan baik bagi guru yang mengajarkan pemecahan masalah ataupun bagi siswa yang mempelajarinya. Berbagai kesulitan itu muncul sebagai akibat pandangan yang keliru, yaitu mencari jawaban sebagai satu-satunya tujuan yang ingin dicapai. Akibat pandangan yang keliru ini siswa sering kali keliru dalam memilih teknik atau strategi pemecahan masalah (Suherman, 2003 : 89). Mengingat akan hal tersebut, maka yang menjadi fokus kajian ini adalah bagaimana strategi pemecahan masalah matematis versi George Polya dan penerapannya dalam pembelajaran matematika?

\section{PEMBAHASAN}

\section{Pengertian Pemecahan Masalah}

Apakah problem (masalah) itu? Problem (dalam matematika) adalah suatu soal atau pernyataan yang menimbulkan tantangan, yang dalam penentuan penyelesaiannya membutuhkan kreativitas, pengalaman, pemikiran asli, atau imajinasi (Posamentier dan Stepelman, 2002 : 53). Suatu soal atau pernyataan dikatakan masalah jika seseorang tidak memiliki aturan tertentu yang segerah dapat digunakan dalam menentukan penyelesaian dari masalah tersebut (Hudojo, 2003 : 48). Dalam menyelesaikan suatu permasalahan dibutuhkan kreativitas, kritis, dan pengetahuan siap dalam suatu situasi yang baru.

Suatu masalah biasanya memuat suatu situasi yang mendorong siswa untuk menyelesaikannya akan tetapi tidak tahu secara langsung apa yang harus dikerjakan untuk menyelasaikannya. Jika suatu masalah diberikan kepada siswa dan siswa tersebut langsung 
mengetahui cara penyelesaiannya dengan benar, maka soal tersebut tidak dapat dikatakan sebagai masalah (Sitorus, 1990). Di sisi lain menyebutkan bahwa suatu pernyataan atau soal matematika merupakan suatu problem bergantung masing-masing individu siswa, ini artinya bagi siswa tertentu suatu pernyataan mungkin merupakan problem sedangkan bagi siswa lain bukan merupakan problem (Wahyudin, 2006). Sebagai contoh, dapat diperhatikan soal berikut ini:

Bila pembilang dan penyebut sebuah pecahan masing-masing dikurangi 5, maka pecahan itu menjadi $\frac{1}{2}$, Bila pembilang dan penyebut masing-masing ditambah 1 maka pecahan itu menjadi $\frac{2}{3}$. Berapakah pecahan yang dimaksud?

Soal tersebut akan merupakan problem bagi siswa SMP, jika siswa tersebut belum pernah menyelesaikan soal semacam itu. Sedangkan bagi siswa yang sudah pernah berhasil menyelesaikan soal tersebut, maka bukan lagi menjadi problem. Dapat dikatakan suatu problem itu relatif, bergantung individu yang menghadapinya.

Apakah pemecahan masalah itu? Menurut National Council of Supervisors of Mathematics (dalam Posamentier dan Stepelman, 2002 : 89) pemecahan masalah adalah proses penerapan pengetahuan yang sudah didapatkan sebelumnya kepada situasi yang baru dan tidak dikenal. Ini berarti suatu soal akan menjadi problem bagi siswa jika siswa sudah memiliki pengetahuan yang dibutuhkan untuk menyelesaikan soal tersebut, tetapi siswa tidak mengetahui produser atau cara unutk menyelesaikannya. Contoh soal diatas dapat dijadikan sebagai soal dalam kegiatan pemecahan masalah di kelas.

\section{Strategi Pemecahan Masalah George Polya}

Membahas tentang pemecahan masalah dalam matematika sukar terlepas dengan tokoh utamanya yaitu George Polya. Menurut Polya (1983), dalam problem solving terdapat langkah-langkah yang perlu dilakukan yaitu: (1) memahami masalah, (2) merencanakan suatu pemecahan, (3) menyelesaikan masalah sesuai dengan rencana langkah kedua, dan (4) memeriksa kembali hasil yang diperoleh. Namun demikian langkah-langkah ini tidaklah menjamin dapat menyelesaikan suatu masalah, hanya dapat membantu.

Langkah-langkah tersebut, yang merupakan sarana umum yang dapat digunakan untuk semua jenis pertanyaan atau problem, di dalamnya berisi serangkai tugas, pemikiran, yang dapat dikombinasikan dinamakan heuristics (Doug, 2007: 1). Selain langkah - 
langkah heuristics yang dikemukakan Polya, ada juga langkah - langkah menurut Krulik dan Rudnick (1980) yaitu : (1) read the problem, (2) explore, (3) select strategy, (4) solve, dan (5) look back .

Jika dicermati langkah-langkah yang dikemukakan Klurik dan Rudnick diatas, ternyata serupa dengan langkah-langkah yang dikemukakan Polya. Yang tampaknya langkah merencanakan suatu pemecahan (devising a plan) pada Polya dipecah menjadi dua bagian dalam Klurik dan Rudnick yaitu menjadi explore dan select strategy. Dari kedua tokoh tersebut diatas dapat dikatakan langkah yang paling esensial dalam pemecahan masalah adalah langkah devising a plan (Polya) atau explore dan select strategy (Klurik dan Rudnick). Diamana dalam langkah ini baik pada Polya maupun pada Klurik dan Rudnick dilakukan persiapan-persiapan berupa pencarian pola (pattern), guess and check, write equation, draw a picrure, make a list, simplifying the problem; dan strategi lainnya.

Oleh karena itu berikut ini yang akan dibahas strategi-strategi yang dapat membantu dalam pemecahan masalah. Adapun strategi-strategi pemecahan masalah diantaranya:

\section{Strategi Act It Out}

Strategi ini dapat membantu siswa dalam proses visualisasi masalah yang tercakup dalam soal yang dihadapi. Dalam pelaksanaannya, dilakukan dengan gerakan-gerakan fisik atau memnggerakkan benda-benda kongkret. Gerakan bersifat fisik dapat membantu atau mempermudah siswa dalam menemukan hubungan antara komponen-komponen yang tercakup dalam suatu masalah.

Pada saat guru memperkenalkan strategi ini, sebaiknya ditekankan bahwa penggunaan obyek kognkrit yang dicontohkan sebenarnya dapat diganti dengan suatu model yang lebih sederhana misalnya gambar. Untuk memperkenalkan strategi ini, ada banyak masalah dalam kehidupan sehari-hari yang dapat digunakan sebagai tema atau konteks masalahnya.

\section{Strategi Membuat Gambar atau Diagram}

Strategi ini dapat membantu siswa untuk mengungkapkan informasi yang terkandung dalam masalah sehingga hubungan antara komponen dalam masalah tersebut dapat terlihat lebih jelas. Pada saat guru mengajarkan strategi ini, hal yang perlu digambar 
atau dibuat diagramnya adalah bagian-bagian terpenting diperkirakan mampu memperjelas permasalahan yang dihadapi.

Contoh: Tempatkan bilangan-bilangan 1,2,3,4,5 di dalam lingkaran dengan ketentuan sebagai berikut: (a). selisih dua bilangan dalam tiap dua lingkaran yang di hubungkan dengan satu garis $\geq 2$ (b). tiap bilangan hanya di gunakan satu kali

\section{Strategi Menemukan Pola}

Kegiatan matematika yang berkaitan dengan proses menemukan suatu pola dari sejumlah data yang diberikan, dapat mulai dilakukan melalui sekumpulan gambar atau bilangan. Kegiatan yang dilakukan antara lain dengan mengobservasi sifat-sifat yang dimiliki bersama oleh kumpulan gambar atau bilangan yang tersedia. Strategi untuk memecahkan masalah, pencarian pola yang pada awalnya hanya dilakukan melalui petunjuk yang diberikan guru, hingga keterampilan itu akan terbentuk dengan sendirinya. Pada saat menghadapi permasalahan tertentu, salah satu pertanyaan yang mungkin muncul di benak seseorang adalah: "adakah pola atau keteraturan tertentu yang mengaitkan tiap data yang diberikan ?" Hal ini tanpa melalui latihan, sangat sulit bagi seorang guru untuk menyadari bahwa dalam permasalahan yang dihadapinya terdapat pola yang dapat diungkap.

\section{Strategi Membuat Tabel}

Penggunaan tabel merupakan langkah yang sangat efisien untuk melakukan klasifikasi serta menyusun sejumlah besar data sehingga apabila muncul sebuah pertanyaan baru berkenaan dengan data tersebut, maka siswa akan dengan mudah menggunakan data tersebut, sehingga jawaban pertanyaan tadi dapat diselesaikan dengan baik.

Contoh: Halim memiliki anyaman kawat sepanjang 24 meter. Kemudian anyaman kawat itu dipotong-potong menjadi 24 bagian yang masing-masing panjangnya 1 meter. Kedua puluh empat anyaman kawat tersebut akan dia pakai untk memagari sebuah kebun berbentuk persegi panjang. Halim menginginkan daerah terluas yang dapat dipagari oleh kedua puluh empat anyaman kawat tadi. Bagaimana seharusnya mengatur pagar itu?

Langkah-langkah penyelesaian sebagai berikut:

\section{Pahami Pertanyaan}

Berapakah luas terbesar dari persegi panjang yang dapat dibuat anyaman kawat sepanjang 24 meter? 
Tiap sisi harus merupakan bilangan bulat dalam meter karena pagar itu akan dibuat dari potongan-potongan anyaman kawat yang masing-masing panjangnya 1 meter. Keliling taman itu mestilah 24 meter.

\section{Rencanakan Strategi dan Selesaikan}

Gunakan sebuah tabel untuk membuat daftar yang teratur baik seperti tabel di bawah ini.

Tabel 1. Daftar Jawaban

\begin{tabular}{ccrc}
\hline Lebar $(\mathbf{m})$ & Panjang $(\mathbf{m})$ & \multicolumn{1}{c}{ Keliling $(\mathbf{m})$} & \multicolumn{1}{c}{ Luas $\left(\mathbf{m}^{2}\right)$} \\
\hline 1 & 11 & $1+11+1+11=24$ & $1 \times 11=11$ \\
2 & 10 & $2+10+2+10=24$ & $2 \times 10=20$ \\
3 & 9 & $3+9+3+9=24$ & $3 \times 9=27$ \\
4 & 8 & $4+8+4+8=24$ & $4 \times 8=32$ \\
5 & 7 & $5+7+5+7=24$ & $5 \times 7=35$ \\
6 & 6 & $6+6+6+6=24$ & $6 \times 6=36$ \\
7 & 5 & $7+5+7+5=24$ & $7 \times 5=35$ \\
\hline
\end{tabular}

Jawaban yang Diharapkan

Taman berbentuk persegi panjang yang berukuran panjang 6 meter memiliki luas terbesar dengan keliling 24 meter.

\section{Periksa Kembali}

Luas terbesar dari taman berbentuk persegi panjang milik Halim yang dapat dipagari dengan anyaman kawat yang sepanjang 24 meter adalah 36m, yaitu taman berebentuk persegi panjang yang panjangnya 6 meter dan lebarnya 6 meter.

\section{Strategi Memperhatikan Semua Kemungkinan Secara Sistematik}

Strategi ini digunakan bersamaan dengan strategi mencari pola dan menggambar tabel. Dalam menggunakan strategi ini, yang perlu di perhatikan adalah semua kemungkinan yang diperoleh dengan cara yang sistematik. Yang dimaksud sistematik disini misalnya dengan mengorganisasikan data berdasarkan kategori tertentu. Namun demikian, untuk masalah-masalah tertentu, mungkin kita harus memperhatikan semua kemungkinan yang bisa terjadi.

\section{Strategi Tebak dan Periksa (Guess and Check)}

Strategi menebak yang dimaksud di sini adalah menebak berdasarkan pada alasan tertentu serta kehati-hatian. Selain itu, untuk dapat melakukan tebakan dengan baik 
seorang guru perlu memiliki pengalaman cukup yang berkaitan dengan permasalahan yang dihadapi. Perhatikan contoh soal guess and check sebagai berikut:

Balok dibawah ini isinya adalah $2880 \mathrm{~cm} 3$. Carilah balok lainnya yang memiliki isinya sama.

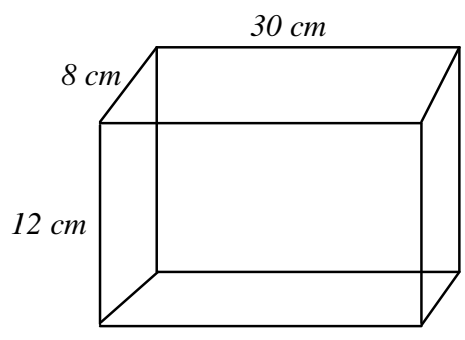

Gambar 1. Balok

\section{Strategi Kerja Mundur}

Suatu masalah kadang-kadang disajikan dalam suatu cara sehingga yang diketahui itu sebenarnya merupakan hasil dari proses tertentu, sedangkan komponen yang ditanyakan merupakan kemponen yang seharusnya muncul lebih awal. Penyelesaian materi seperti ini biasanya dapat dilakukan dengan menggunakan strategi mundur. Contoh masalahnya adalah sebagai berikut.

Jika dua bilangan bulat adalah 12, sedangkan hasil kalinya 45, tentukan kedua bilangan tersebut.

Ingat: langkah awal menentukan apa yang diketahui, apa yang ditanyakan, dan informasi yang diperlukan.

Strategi ini merupakan cara penyelesaian yang sangat terkenal sehingga seringkali muncul dalam soal - soal matematika sederhana di sekolah.

\section{Strategi Menggunakan Kalimat Terbuka}

Strategi ini juga termasuk sering diberikan dalam soal-soal matematika sederhana di Sekolah Dasar. Walaupun strategi ini termasuk sering digunakan, akan tetapi pada langkah awal siswa sering kali mendapat kesulitan untuk menentukan kalimat terbuka yang sesuai. Untuk sampai pada kalimat yang dicari, seringkali harus melalui penggunaan startegi lain, dengan maksud agar hubungan antar unsur yang terkandung di dalam masalah dapat dilihat secara jelas. Setelah itu baru dibuat kalimat terbukanya.

Contoh masalah yang dapat diselesaikan degan menggunakan satrategi kalimat terbuka.

Dua pertiga dari suatu bilangan adalah 24 dan setengah dari bilangan tersebut adalah 18. Berapakah bilangan tersebut? 
Sebuah soal adakalanya sangat sulit untuk diselesaikan karena didalamnya terkandung permasalahan yang cukup kompleks misalnya menyangkut bilangan yang sangat besar dan atau berkaitan dengan pola yang cukup kompleks. Untuk menyelesaikan masalah seperti ini, dapat dilakukan dengan menggunakan analogi melalui penyelesaian masalah yang mirip atau masalah yang lebih mudah.

\section{Strategi mengubah sudut pandang}

Strategi ini seringkali digunakan setelah kita gagal untuk menyelesaikan masalah dengan menggunakan strategi lain. Waktu kita mencoba menyelesaikan masalah, sebenarnya kita mulai dengan suatu sudut pandang tertentu atau mencoba menggunakan asumsi-asumsi tertentu. Setelah kita mencoba menggunakan suatu strategi dan ternyata gagal, kecenderungannya adalah kembali memperhatikan soal dengan menggunakan sudut pandang yang sama. Jika setelah menggunakan startegi lain ternyata masih tetap menemui kegagalan, cobalah untuk mengubah sudut pandang dengan memprbaiki asumsi atau memeriksa logika berpikir yang digunakan sebelumnya. Contoh penggunaan strategi ini dapat dilakukan soal berikut.

Ada berapa segitiga pada gambar berikut ini ?

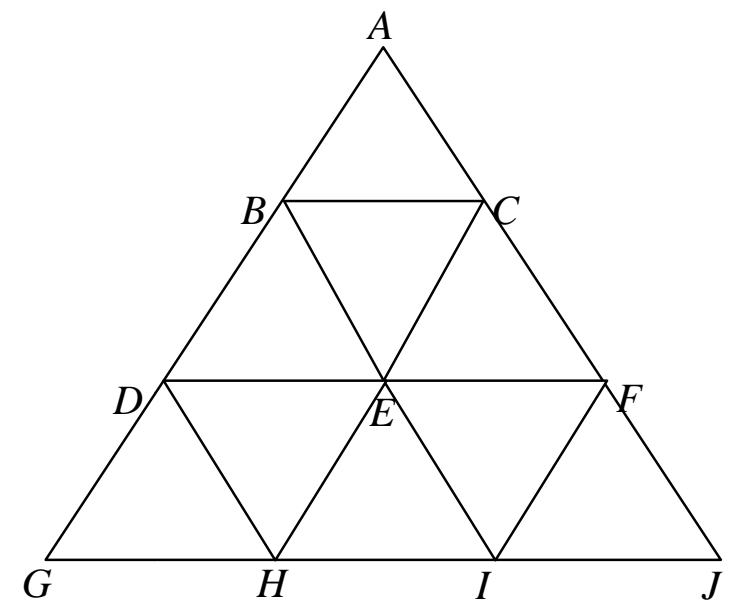

Gambar 2. Segitiga Kombinasi

\section{Beberapa Contoh Strategi Pemecahan Masalah Dalam Pembelajaran Matematika}

Dalam melakukan pemecahan masalah, strategi-strategi di atas bisa digunakan secara terpisah, tetapi digunakan secara gabungan atau kombinasi. Contoh-berikut diharapkan dapat memberi ilustrasi bagaimana penggunaan strategi pemecahan masalah yang dikemukakan di atas. 
Contoh 1: Tentukan nilai dari : $2-4+6-8+10-12+\ldots-200$

Penyelesaian: Strategi yang digunakan adalah simplifying: solve for simpler problem dan look for a pattern. Ketika berhadapan dengan masalah ini, kemungkinan ditemukan suatu pola (pattern). Namun merupakan pola yang panjang dan banyak pengunggulan. Menyelesaikan pola yang sama untuk masalah yang lebih sederhana akan sangat membatu dalam menyelesaikan soal tersebut.

Pertama-tama dapat diperhatikan : $2-4+6-8+10-12+14-16+18-20$, ini dapat ditulis menjadi : $(2-4)+(6-8)+(10-12)+(14-16)+(18-20)=(-2)+(-2)+(-2)+(-$ $2)+(-2)=5(-2)$. Dari 2 sampai 20 ada 5 pasang yang menghasilkan 5(-2). Oleh karena itu, dari 2 sampai 200 terdapat 50 pasang yang dihasilkan 50 (-2). Jadi jumlahnya $50(-2)=-$ 100, Jadi, jawaban yang didapatkan adalah - 100 .

Contoh 2 : Tentukan huruf ke 500 dari kata REALISTIKREALISTIKREALISTIK...

REALISTIKRELISTIK<smiles></smiles>

Kata "REALISTIK" terdiri dari 9 huruf, sehingga $500: 9=55 \longrightarrow$ sisa 5

R E A L I S T I K

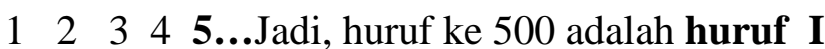

Untuk soal dibawah ini dapat dijadikan tugas rumah sebagai refleksi.

1. SMP Mutiara hanya memiliki tim bola voli, renang, sepak bola, dan basket. Erika, Yahya, Maya, dan Dudi masing-masing adalah pemain olahraga yang berbeda. Olahraga yang dimainkan Yahya tidak menggunakan bola. Maya lebih tua daripada pemain bola voli. Maya dan Dudi bukan pemain sepak bola. Siapakah pemain bola voli?

2. Dalam suatu perlombaan, mobil A berada pada urutan yang 147 jika dilihat dari garis strat, dan menempati urutan ke 198 jika dilihat garis finis. Berapa banyak mobil yang ikut dalam perlombaan tersebut?

3. Bola Mardona membentuk suatu piramida dengan alasnya berbentuk persegi, seperti gambar 3 berikut ini. 


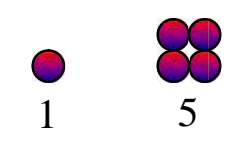

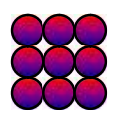

14

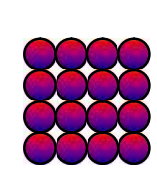

30

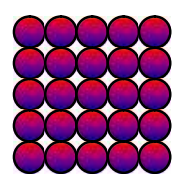

55

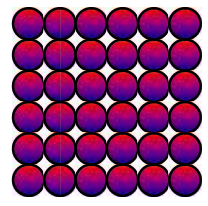

Gambar 3. Bola Mardona

a. Berapa banyak bola Mardona pada gambar ke-6?

b. Gunakanlah metode lain untuk menemukan banyaknya bola Mardona pada gambar ke-8?

c. Deskripsikan piramida ke-10 dan tentukan banyak bola Mardona pada gambar ke-10?

\section{KESIMPULAN DAN SARAN}

Demikian uraian tentang strategi pemecahan masalah matematis versi George Polya dan penerapannya dalam pembelajaran matematika. Hal ini baru merupakan langkah awal dalam membiasakan kegiatan pemecahan masalah matematis siswa di kelas. Jika guru selalu membiasakan melakukan pemecahan masalah, diharapkan siswa akan menjadi problem solver atau pemecahan masalah yang handal, baik dalam belajar matematika maupun dalam kehidupan sehari-hari. Tujuan mengajarkan matematika dengan pemecahan masalah adalah: (1) membantu guru memperbaiki keterampilan pemecahan masalah diri sendiri; (2) diberikan kepada guru untuk membantu siswa mengembangkan keterampilan pemecahan masalah mereka; (3) untuk menyelidiki strategi umum pemecahan masalah; dan (4) bagaimana membuat kata "masalah" dan "pemecahan masalah" menantang dan menarik untuk siswa.

Adapun sepuluh strategi yang digunakan dalam pemecahan masalah matematika yaitu: bekerja mundur, menemukan pola, mengambil suatu sudut pandang yang berbeda, memecahkan suatu masalah yang beranalogi dengan masalah yang sedang dihadapi tetapi lebih sederhana, mempertimbangkan kasus-kasus ekstrim, membuat gambar, menduga dan menguji berdasarkan akal, memperhitungkan semua kemungkinan, mengorganisasikan data, dan penalaran logis. Siswa perlu didorong untuk berpikir bahwa sesuatu itu multidimensi sehingga mereka dapat melihat banyak kemungkinan penyelesaian untuk suatu masalah, misalnya dengan mempertimbangkan berbagai solusi yang didapatkan oleh teman-teman sekelas dan membandingkannya pada solusi atau penyelesaian yang "baku" yaitu, yang diberikan dalam buku-buku teks atau yang disajikan oleh guru matematika. 


\section{REFERENSI}

Depdiknas (2006). Kurikulum 2004 Standar Kompetensi Mata Pelajaran Matematika, Jakarta: Depdiknas

Doug, C. (2007) "Mathematical Problem Solving”. Diperoleh dari http://www.qerhs.kl2.nf.ca/projects/math-problem/nitro.html (2015, Desember 18).

Hudojo, H. (2003). Common Textbook Pengembangan Kurikulum dan Pembelajaran Matematika, Malang: JICA.

Katz, L G. (2009). Dispositions as Educational Goals. Diperoleh dari http://www.edpsycinteractive.org/files/edoutcomes.html. (2015, Desember 18).

Krulik, S. Dan Robert E. Rayes: Problem Solving in School mathematics. Virginia. NCTM (1980)

NCTM. (1989). Curriculum and Evaluation Standards for School Mathematics. Diperoleh dari http://www.krellinst.org/AiS/textbook/manual/stand/NCTME_stand.html. (2015, Desember 5).

NCTM. (2001) Principles and Standards for School Mathematics. Reston, VA NCTM.

NCTM, (2003). The Roles of Representations in School Mathematics. Reston Virginia.

Polya, G. (1983) How To Solve It. Princeton, New Jersey: Princeton University Press.

Posamentier, A.S., dan Stepelman, J (2002) Teaching Secondary School Mathematics Teacniques and Enrichment Units, Ohio: Merril Publishing Company.

Sitorus, J. (2009). Pembaharuan Pengajaran Matematika Sekolah. Bandung. Tarsito

Suherman, Ar., (2003). Common Text Book Strategi Pembelajaran Matematika Kontemporer, Bandung: JICA. 